\title{
CALCULATING FRICTION FORCE AND THERMAL ACTION OF A JET ENGINE JET ON THE INNER SURFACE OF A TUBULAR GUIDE
}

\author{
Oleksandr M. Shyiko ${ }^{a}$, Anatoly M. Pavlyuchenko ${ }^{\mathrm{b}}$, \\ Olexii A. Obukhov ${ }^{\mathrm{C}}$ \\ a National Agricultural University, Sumy, Ukraine, \\ e-mail: shyikoa@ukr.net, corresponding author, \\ ORCID iD: Dhttp://orcid.org/0000-0002-4297-911X \\ ${ }^{\mathrm{b}}$ National Agricultural University, Sumy, Ukraine, \\ e-mail: apavlucenko22@gmail.com, \\ ORCID iD: (Dhttps://orcid.org/0000-0003-0827-2847 \\ ${ }^{c}$ Research Center of Rocket Forces and Artillery, Sumy, Ukraine, \\ e-mail: obukhov.olexii@gmail.com, \\ ORCID iD: (1)https://orcid.org/0000-0003-0846-2288
}

DOI: 10.5937/vojtehg68-24619; https://doi.org/10.5937/vojtehg68-24619

FIELD: Mechanics, Artillery and Rocket Weapons

ARTICLE TYPE: Original scientific paper

ARTICLE LANGUAGE: English

\section{Summary:}

Introduction/purpose: To study the dynamics of launchers with sources of high-energy gas jets, it is relevant to calculate shear forces from the action of a high-temperature supersonic jet on the inner surface of a cylindrical channel and the temperature of the channel walls. The aim of this work is to develop a comprehensive method for calculating aerodynamic friction and heating on the inner surface of a tubular guide of a rocket.

Methods/results: The research method is based on the theory of supersonic gas flows in cylindrical channels and the theory of the boundary layer. The gas jet is considered continuous, stationary and axisymmetric. The system of differential equations of motion of the projectile in the guide integrates numerically over time. The flow parameters in the pipe sections are found according to the dependences of the theory of supersonic gas flows, taking into account friction losses. To calculate shear stress on the guide wall, we use the relations of the asymptotic theory of the turbulent boundary layer, the theory of turbulent spots of Emmons of the transition boundary layer, and data on the Reynolds numbers of the beginning of the laminar-turbulent transition in wind tunnels. At the same time, the differential equation for heating the thin wall of the guide in the range of contact between the surface of the guide and the jet is numerically integrated. The calculations of the distribution of flow parameters, friction force and the temperature of the 
wall of the tubular guide during the movement of the projectile inside the jet from the moment the engine is started to the moment the shell exits completely from the guide are performed and graphically presented.

Conclusions: This method of calculating aerodynamic friction and heating on the inner surface of a tubular guide of a rocket due to a high temperature supersonic gas jet - taking into account the effects of nonisothermality, compressibility and laminar-turbulent transition in the boundary layer - can be used to study the dynamics of the launch of rockets from launchers equipped with tubular guides.

Keywords: launcher, tubular guide, rocket, engine jet, boundary layer, friction force of the jet, heating the tubular guide.

\section{Introduction}

The movement of certain mechanical objects in cylindrical channels, for example, rockets in tubular guides of launchers (Fig. 1), occurs under the influence of a high-temperature supersonic gas jet. To ensure strength from power and thermal load of the jet, to create physical and mathematical models of the dynamics of propulsion systems with sources of high-energy gas jets, it is relevant to calculate the normal and tangential forces from the action of a high-temperature supersonic jet on the inner surface of the cylindrical channel and the temperature of the channel walls.

Many publications devoted to the oscillations of launchers at the launch of rockets from tubular guides do not take into account the action of gas-dynamic friction forces on the inner surface of the tubular guide from the side of the high-energy high-temperature jet of gases from the rocket engine during its movement inside the tubular guide (Svetlickij, 1986), (Somoiag et al, 2007, pp.95-97), (Dziopa et al, 2015, pp.72-73). Some of these publications (Antunevich et al, 2017, pp.209-210), (Svetlickij, 1986) contain an indication of the need to use the pressure of the gas jet in the calculations of launcher oscillations. At the same time, the content embedded in this concept is not disclosed and the method for calculating the force is not described.

In his work, Bogomolov (2003, pp.89-97) describes in detail a method for calculating the friction force of a gas jet of a jet engine on the inner surface of a tubular guide. The disadvantage of the described method is that the calculation of the friction force is based on the equations of an incompressible fluid, without taking into account the compressibility of the jet and heating of the guide wall. 


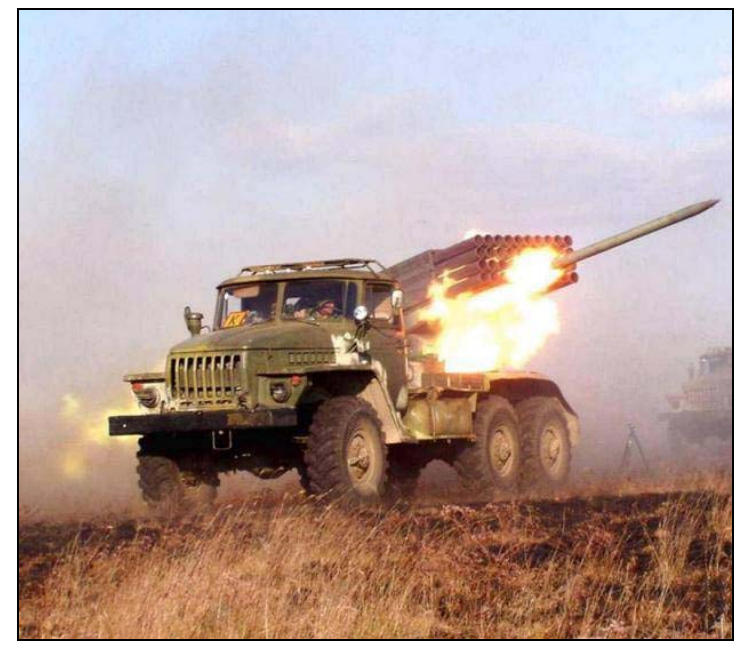

Figure 1 - Mobile launcher with a tubular guide

Puc. 1 - Мобильная пусковая установка с трубчатой направляющей Слика 1 - Самоходни вишецевни ракетни лансер

\section{Purpose of the research}

This work aims at developing a comprehensive method for calculating aerodynamic friction and heating on the inner surface of a rocket tubular guide from the action of a high-temperature supersonic gas jet. The calculation method should take into account the effects of non-isothermality, compressibility and laminar-turbulent transition in the boundary layer on the streamlined inner surface of the tubular guide. The aim is also to perform and graphically present the calculations of the distribution of flow parameters, friction force, and the temperature of the wall of the tubular guide when the projectile moves inside the tubular guide from the moment the engine starts and until the projectile completely leaves the guide.

\section{Presentation of the main material}

In this paper, we consider the methodology and the results of calculating the time-variable total friction force on the inner surface of a cylindrical channel and heating a thin channel wall from the passage of a source of a high-temperature supersonic gas jet. The calculation is performed under the following assumptions: the gas jet is continuous, stationary, one-dimensional and axisymmetric; the parameters at the beginning of the jet are determined by the parameters in the outlet 
section of the nozzle of the jet source and are constant over the pipe section. Constant along the pipe cross section, the average flow parameters in the channel are found according to the dependences of the theory of adiabatic supersonic gas flows in cylindrical channels of a constant cross section, taking into account friction losses. The calculation of the friction force and heating of the wall of the tubular guide is carried out using the calculation model of the translational motion of the projectile in the guide (Fig. 2).

The system of differential equations for the accelerated motion of the center of mass of the projectile takes into account the action of the engine's traction force $\vec{P}$, the force of gravity $\overrightarrow{\mathrm{Mg}}$, the friction force $\vec{F}_{T}$, the support reaction $\vec{R}$, and the components of the helical groove reaction $\overrightarrow{\mathrm{N}}_{\mathrm{x}}$ and $\overrightarrow{\mathrm{N}}_{\mathrm{y}}$. The system of equations is solved numerically by the Runge-Kutta method. At each next step of numerical integration, there is an elementary movement of the projectile inside the tubular guide and the flow parameters are calculated in the interval between the engine nozzle cross section and the cross section of the tubular guide exit. At the same time, the numerical integration of the differential equation for heating the wall of the tubular guide in this interval occurs. The calculations occur in the following sequence.

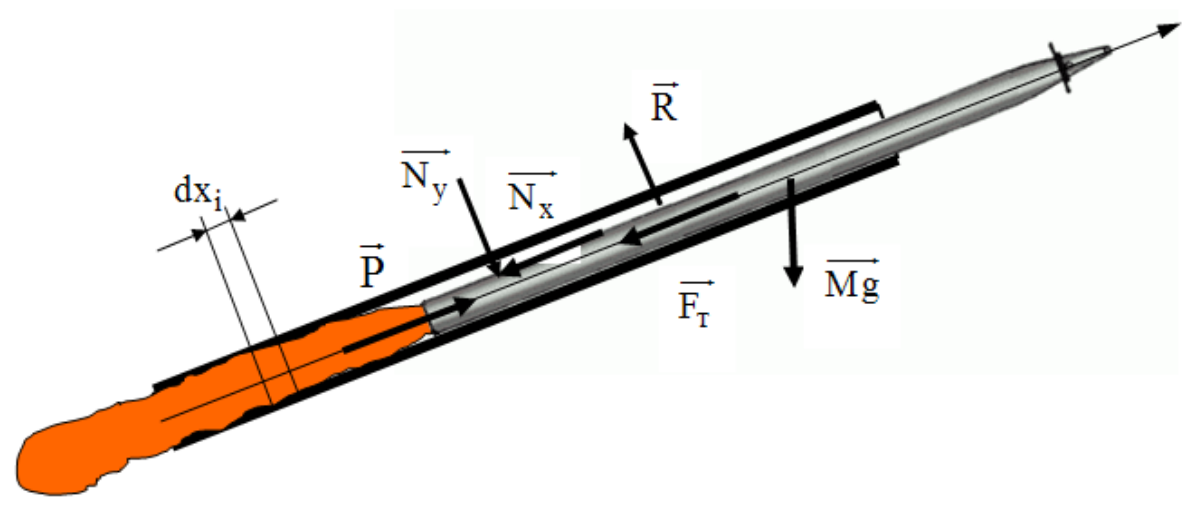

Figure 2 - Calculation model of the movement of the projectile in the tubular guide Puc. 2 - Расчетная модель движения снаряда в трубчатой направляющей Слика 2 - Модел прорачуна кретања пројектила у лансирној цеви

The gas flow velocity at the nozzle exit of the jet engine will be found by the dependence (Abramovich, 1991) 


$$
V_{a}=\lambda_{a} \cdot a_{\kappa p}=\lambda_{a} \cdot \sqrt{\frac{2 k}{k+1} \cdot R_{\mu} \cdot T_{\kappa}}
$$

where $\lambda_{\mathrm{a}}$ - the relative velocity at the nozzle exit of the engine, $a_{\text {кр }}$ - the critical velocity of the gas stream; $T_{\kappa}-$ the temperature in the engine chamber; $\mathrm{k}$ - the adiabatic index; and $\mathrm{R}_{\mu}$ - the specific gas constant. The pressure, density and temperature of the gas at the nozzle exit of the jet engine will be found from the corresponding known dependencies for the adiabatic flow:

$$
\begin{gathered}
p_{a}=p_{c} \cdot\left(1-\frac{k-1}{k+1} \cdot \lambda_{a}^{2}\right)^{\frac{k}{k-1}} ; \rho_{a}=\rho_{c} \cdot\left(1-\frac{k-1}{k+1} \cdot \lambda_{a}^{2}\right)^{\frac{1}{k-1}} ; \\
\mathrm{T}_{\mathrm{a}}=\mathrm{T}_{\mathrm{K}} \cdot\left(1-\frac{\mathrm{k}-1}{\mathrm{k}+1} \cdot \lambda_{\mathrm{a}}^{2}\right)
\end{gathered}
$$

The relative velocity $\lambda_{\mathrm{a}}$ at the nozzle exit of the engine is obtained by solving the $\lambda_{\mathrm{a}}$ equation (Abramovich, 1991)

$$
\lambda_{a} \cdot\left(\frac{k+1}{2}\right)^{\frac{1}{k-1}} \cdot\left(1-\frac{k-1}{k+1} \cdot \lambda_{a}^{2}\right)^{\frac{1}{k-1}}=q\left(\lambda_{a}\right)
$$

In this case, the reduced mass flux density at the nozzle exit $q\left(\lambda_{a}\right)$ is equal to the ratio of the mass flux density $\left(\rho_{\mathrm{a}} \cdot \mathrm{V}_{\mathrm{a}}\right)$ at the nozzle exit to the mass flux density in the critical nozzle section. For the known areas of the critical $\mathrm{S}_{\text {кр }}$ and output $\mathrm{S}_{\mathrm{a}}$ sections of the nozzle, we perform a calculation from the dependence $\mathrm{q}\left(\lambda_{\mathrm{a}}\right)=\mathrm{S}_{\mathrm{Kp}} / \mathrm{S}_{\mathrm{a}}\left(\rho_{\mathrm{K}}, \mathrm{V}_{\mathrm{K}}-\right.$ the density and velocity of the gas flow in the critical section of the nozzle, respectively).

The relative velocity $\lambda_{i}$ in the section is related to the relative velocity in the previous section $\lambda_{i-1}$ by the specific work of the friction forces with the following dependence (Abramovich, 1991): 


$$
\frac{1}{\lambda_{i-1}^{2}}-\frac{1}{\lambda_{i}^{2}}-\ln \left(\frac{\lambda_{i}^{2}}{\lambda_{i-1}^{2}}\right)=\frac{2 k}{k+1} \cdot \xi_{i-1} \cdot \frac{d x_{i}}{D}
$$

The friction drag coefficient of the elementary region $\xi_{i}$ is determined by the Nikuradze formula for the turbulent adiabatic flow of an incompressible fluid in a technically smooth cylindrical channel

$$
\xi_{i}=0.0032+0.221 / \operatorname{Re}_{i}^{0.237},
$$

where the local Reynolds number $\mathrm{Re}_{\mathrm{i}}=\mathrm{V}_{\mathrm{i}} \cdot \mathrm{D} / \mathrm{v}_{\mathrm{i}} ; \mathrm{V}_{\mathrm{i}}, \mathrm{v}_{\mathrm{i}}$ - average velocity and kinematic viscosity of the flow in the elementary region. In the future, when calculating all other parameters of the gas jet, we will consider them as the average cross section. Due to the constant braking temperature, the critical velocity along the pipe also does not change. In connection with this, the ratio of the relative velocities in the pipe sections is equal to the ratio of velocities and, based on the continuity equation, the inverse ratio of densities. The velocity and density in an arbitrary section is related to the velocity and density in the previous section of the pipe by the given velocities as follows:

$$
V_{i}=V_{i-1} \cdot \frac{\lambda_{i}}{\lambda_{i-1}} ; \quad \rho_{i}=\rho_{i-1} \cdot \frac{\lambda_{i-1}}{\lambda_{i}}
$$

In this case, the static pressure in an arbitrary section of the tubular guide $p_{i}$ is expressed through the pressure $p_{i-1}$ in the previous section, the relative velocity in this and the previous section of the pipe in this way (Abramovich, 1991)

$$
p_{i}=p_{i-1} \cdot\left(1-\frac{k-1}{k+1} \cdot \lambda_{i}^{2}\right) /\left(1-\frac{k-1}{k+1} \cdot \lambda_{i-1}^{2}\right) \cdot \frac{\lambda_{i-1}}{\lambda_{i}}
$$

where $\lambda_{i}-$ the relative velocity in the tubular guide section, and $\lambda_{i-1}-$ the relative velocity in the previous tubular guide section.

The dependence of the kinematic viscosity coefficient $v_{i}\left(\mathrm{~m}^{2} / \mathrm{s}\right)$ on pressure is taken into account using the dependence (Bogomolov, 2003)

$$
v_{\mathrm{i}}=5.35 / \mathrm{p}_{\mathrm{i}}
$$

where $p_{i}$ is the static pressure $p$ according to $(7)$ in $\mathrm{kgf} / \mathrm{m}^{2}$. 
The elementary friction force is determined using the theory of the boundary layer. Depending on the values of the Reynolds number calculated from the average values of the flow parameters in the channel, the flow in each elementary section of the pipe is considered laminar, transitional or developed turbulent. The calculated value of the Reynolds number of the beginning of the laminar-turbulent transition is taken from the given experiments on the transition in supersonic wind tunnels. The average values of the flow parameters in the guide tube calculated from dependences $(6) \div(7)$ are taken as the values of the flow parameters at the outer boundary of the boundary layer (velocity $u_{e}=V_{i}$, static pressure $p_{e}=p_{i}$, density $\rho_{e}=\rho_{i}$ ).

To determine the local coefficient of friction in the boundary layer on the inner surface of the tubular guide in the case of a laminar boundary layer, the known dependences are used for the longitudinal flow around a flat plate taking into account non-isothermality (Kutateladze, 1979)

$$
C_{f l}=C_{f 0} \cdot \psi^{-0,11} \cdot \psi^{*}-0,04
$$

where $\psi, \psi^{*}$ are the parameters that take into account the nonisothermal flow around the flat plate with the laminar boundary layer; $\psi=\mathrm{T}_{\mathrm{w}} / \mathrm{T}_{\mathrm{r}, \mathrm{e}}$ - the temperature factor, $\psi^{*}=\mathrm{T}_{\mathrm{r}, \mathrm{e}} / \mathrm{T}_{\mathrm{e}}-$ the kinetic temperature factor; $T_{W}$ - the temperature of the surface of the channel wall; $\mathrm{T}_{\mathrm{e}}-$ the temperature at the outer boundary of the boundary layer; $\mathrm{T}_{\mathrm{re}}$ - the temperature recovery boundary layer; $\mathrm{C}_{\mathrm{f} 0}-$ the local coefficient of friction for the laminar boundary layer of an incompressible fluid on a flat longitudinally streamlined plate with the same Reynolds number on the outer boundary of the boundary layer, which can be calculated, for example, according to the Blasius formula (Kutateladze, 1979)

$$
C_{f 0}=\frac{0,664}{\sqrt{\operatorname{Re}_{e}}} ; \quad R e_{x, e}=\frac{\rho_{e} \cdot u_{e} \cdot X}{\mu_{e}}
$$

where $X$ is the distance from the nozzle exit of the gas stream source to the place of determination of the Reynolds number of the elementary section of the channel and $\mu_{\mathrm{e}}$ is the dynamic coefficient of viscosity of fuel combustion products at the outer boundary of the boundary layer. 
The recovery temperature $T_{r, e}$ calculated from the parameters $T_{e}$ and $\mathrm{M}_{\mathrm{e}}$ at the outer boundary of the laminar boundary layer (Kutateladze, 1979) is

$$
T_{r e}=T_{e} \cdot\left(1+r_{\pi} \frac{k-1}{2} \cdot M_{e}^{2}\right) ; \quad r_{\Omega}=\sqrt{\operatorname{Pr}}
$$

For gases, the Prandl number practically does not change with temperature (for diatomic gases $\operatorname{Pr} \geq 0.72$, for triatomic and polyatomic gases $0.75 \leq \operatorname{Pr} \leq 1)$. We find the Mach number $M_{e}$ at the outer boundary of the boundary layer by recalculating relative velocity in the elementary section $\lambda_{i}$, determined by dependence (4), into the Mach number in this section, assuming the indicated gas flow parameters to be constant along the length of the guide elementary section:

$$
M_{e}^{2}=M_{i}^{2}=\left(\frac{2}{k+1} \cdot \lambda_{i}^{2}\right) /\left(1-\frac{k-1}{k+1} \cdot \lambda_{i}^{2}\right)
$$

The non-isothermal flow of a high-temperature supersonic gas stream around the inner surface of the tubular guide is taken into account using the temperature of the guide wall, which is included in the expressions for the temperature factor $\psi=\mathrm{T}_{\mathrm{w}} / \mathrm{T}_{\mathrm{r}, \mathrm{e}}$, using the differential heat balance equation for a thin wall (Leontiev \& Pavlyuchenko, 2008):

$$
\rho_{w} \cdot c_{w} \cdot \delta_{w} \cdot \frac{d T_{w}}{d \tau}=\alpha \cdot\left(T_{r, e}-T_{w}\right)
$$

where $T_{w}$ - the wall temperature; $\tau$ - the time; $\rho_{w}, c_{w}, \delta_{w}-$ the wall density, heat capacity and thickness; $\alpha$ - the heat transfer coefficient for external laminar or turbulent flow.

In the case of a laminar flow regime, the heat transfer coefficient $\alpha_{l}$ according to the formula containing the Stanton number St (Kutateladze, 1979) reads:

$$
\alpha_{l}=S t_{l} \cdot \rho_{e} \cdot u_{e} \cdot c_{p, e}
$$

where

$$
S t_{l}=\frac{0,332}{\sqrt{\operatorname{Re}_{x, e}}} \cdot \frac{\sqrt{\psi_{l}}}{\operatorname{Pr}^{2 / 3}} ; \quad \psi_{l}=\psi^{-0,22} \cdot \psi^{*-0,08}
$$

$\rho_{\mathrm{e}}, \mathrm{u}_{\mathrm{e}}, \mathrm{c}_{\mathrm{p}, \mathrm{e}}$ - the density, speed and heat capacity, respectively, of the fuel combustion products in the solid propellant rocket engine at the outer boundary of the boundary layer in the guide tube at constant pressure. 
To calculate the local coefficient of friction and the heat transfer coefficient in the boundary layer on the inner surface in the guide tube in the case of a turbulent boundary layer, we use the results of the asymptotic theory of the turbulent boundary layer by academicians S.S. Kutateladze and A.I. Leontiev. The theory is valid both for Reynolds numbers $\mathrm{Re} \rightarrow \infty$ and for their arbitrarily large finite values. Based on this theory, the method of calculating heat transfer and friction has demonstrated its effectiveness in solving complex problems of heat transfer and turbulent friction both in internal flow conditions (nozzles, heat exchangers, etc.) and in solving aerodynamic problems in external flow. An important advantage of the method is its efficiency and, to a certain extent, universality, which is determined by the possibility of separately accounting for the influence on heat transfer and friction of compressibility, non-isothermal and longitudinal pressure gradient by the corresponding relative laws of friction when calculating heat transfer and surface friction resistance in a boundary turbulent layer.

In accordance with (Kutateladze et al, 1985), the local coefficient of friction for a non-isothermal compressible turbulent boundary layer can be calculated from the dependence:

$$
C_{f T}=C_{f 0} \cdot\left(\Psi_{M} \cdot \Psi_{t}\right)^{0,8} \cdot\left(\frac{\mu_{w}}{\mu_{e}}\right)^{0,2}, \quad C_{f 0}=0,0576 \cdot R e_{x, e}^{-0,2}, R e_{x, e}=\frac{\rho_{e} \cdot u_{e} \cdot x}{\mu_{e}},
$$

$\mathrm{C}_{\mathrm{f} 0}$ - the local coefficient of friction for a turbulent boundary layer of an incompressible fluid on a flat plate is the same $\mathrm{Re}_{\mathrm{x}, \mathrm{e}} ; \mu_{\mathrm{w}}, \mu_{\mathrm{e}}$ - the value of the dynamic viscosity coefficient of the liquid at the wall temperature $\mathrm{T}_{\mathrm{w}}$ and the flow temperature at the outer boundary of the boundary layer $\mathrm{T}_{\mathrm{e}}$, respectively; $\mathrm{Re}_{\mathrm{x}, \mathrm{e}}$ - the Reynolds number at the outer boundary of the boundary layer, which is determined taking into account the dependence of the velocity $u_{e}$ on the longitudinal pressure gradient $\operatorname{gradP}_{\mathrm{x}} ; \Psi_{\mathrm{M}}$ and $\Psi_{\mathrm{t}}$ - relative laws of friction resistance, taking into account compressibility and non-isothermality in the boundary layer, respectively

$$
\Psi_{\mathrm{M}}=\left[\frac{\operatorname{arctg}\left\{\mathrm{M}_{\mathrm{e}} \cdot \sqrt{\mathrm{r}_{\mathrm{T}} \cdot \frac{\mathrm{k}-1}{2}}\right\}}{\mathrm{M}_{\mathrm{e}} \cdot \sqrt{\mathrm{r}_{\mathrm{T}} \cdot \frac{\mathrm{k}-1}{2}}}\right]^{2} ; \quad \Psi_{\mathrm{t}}=\left[\frac{2}{\sqrt{\frac{\mathrm{T}_{\mathrm{w}}}{\mathrm{T}_{\mathrm{r}, \mathrm{e}}}}+1}\right]^{2},
$$


$\mathrm{T}_{\mathrm{r}, \mathrm{e}}$ - the recovery temperature calculated by the parameters $\mathrm{T}_{\mathrm{e}}$ and $\mathrm{M}_{\mathrm{e}}$ at the outer boundary of the turbulent boundary layer; $r_{T}=\sqrt[3]{\mathrm{Pr}}$-the coefficient of temperature recovery for a turbulent boundary layer; $\mathrm{Pr}$ the Prandtl number; $k=1.25$ (Bogomolov, 2003) is the adiabatic index of the propellant products of solid propellant combustion. The Stanton number, which determines the heat transfer in a non-isothermal compressible turbulent boundary layer to the surface of the streamlined body, in accordance with (Kutateladze et al, 1985), can be calculated from the following relationships:

$$
S t_{T}=S t_{0} \cdot\left(\Psi_{M} \cdot \Psi_{t}\right)^{0,8} \cdot\left(\frac{\mu_{w}}{\mu_{e}}\right)^{0,2} ; \quad S t_{0}=0,0288 \cdot \operatorname{Re}_{e, x}^{-0,2} \cdot \operatorname{Pr}^{-2 / 3},
$$

In this case, the heat transfer coefficient for a non-isothermal compressible turbulent boundary layer has the expression:

$$
\alpha_{T}=S t_{T} \cdot \rho_{e} \cdot u_{e} \cdot c_{p, e}
$$

The calculation of the local values of the coefficient of friction and the heat transfer coefficient on the inner surface of the tubular guide under conditions of laminar-turbulent transition is carried out using the theory of turbulent spots of Emmons (Emmons, 1951, p.490). According to Emmons, the transition region is characterized by the alternating appearance of turbulent spots which do not interact with each other and which, expanding along the flow, merge to form a turbulent boundary layer. The intermittency of turbulent spots relative to a streamlined surface is characterized by the alternation of laminar and turbulent flows in the transition zone. This process is quantified using the intermittency coefficient $\gamma$. The expressions for $\gamma$, which varies from 0 to 1 , are used in calculating the coefficients of friction and heat transfer resistance in the region of the laminar-turbulent transition using the values of the friction and heat transfer coefficients for the laminar and turbulent flow regimes under given conditions at the outer boundary of the boundary layer.

In (Chen \& Thyson, 1971, p.821), on the basis of the theory of Emmons's turbulent spots and the established relationship between the spot formation rate and the Reynolds number at the beginning of the transition zone, an expression was obtained for the intermittency coefficient which is valid for a laminar-turbulent flow around a thermally insulated surface: 


$$
\begin{gathered}
\gamma=1,0-\exp \left[-G_{l} \cdot\left(x-x_{H}\right)^{2} / u_{e}\right], \\
G_{I}=\frac{3,507}{A^{2}} \cdot \operatorname{Re}_{t r}^{-1,34} \cdot \frac{u_{e}^{3} \cdot \rho_{e}^{2}}{\mu_{e}^{2}}, \quad A=60+4,68 \cdot M_{e}^{1,92}
\end{gathered}
$$

where $\mathrm{G}_{1}$ - the velocity of formation of turbulent spots; $\mathrm{x}_{\mathrm{H}}$ - the longitudinal coordinate of the point of the beginning of the laminarturbulent transition in the boundary layer; $\mathrm{Re}_{\mathrm{tr}}$ - the Reynolds number at the beginning of the transition zone.

In the case of the laminar-turbulent transition in the supersonic boundary layer, the heat balance equation for a thin wall under the Biot criterion Bi $\square 1.0$ has the form (Leontiev \& Pavlyuchenko, 2008)

$$
\rho_{w} \cdot c_{w} \cdot \delta_{w} \cdot \frac{d T_{w}}{d \tau}=\left[\alpha_{l} \cdot(1-\gamma)+\alpha_{T} \cdot \gamma\right] \cdot\left(T_{r, e}-T_{w}\right)
$$

where $\alpha_{1}$ and $\alpha_{T}$ are the heat transfer coefficients for laminar and turbulent flows in the boundary layer, respectively, according to dependences (14) and (18).

If the Reynolds numbers at the points of the streamlined surface reach the beginning of the laminar-turbulent transition $\operatorname{Re}_{t r}$, the calculation of the local friction coefficient in the transition zone should be carried out according to

$$
C_{f}=C_{f l} \cdot(1-\gamma)+C_{f T} \cdot \gamma
$$

where $\mathrm{C}_{\mathrm{fl}}$ and $\mathrm{C}_{\mathrm{fT}}$ are the local friction coefficients for the laminar and turbulent boundary layer and $\gamma$ is the intermittency coefficient according to dependence (19). The elementary friction force of a gas jet in a section of a rocket tube guide with a diameter $D$ is determined by the local coefficient of friction, the velocity-head of the stream, calculated from the parameters at the outer boundary of the boundary layer, and the area of the elementary section of the inner surface of the tubular guide:

$$
F_{i}=c_{f} \cdot \frac{\rho_{i} \cdot V_{i}^{2}}{2} \cdot S_{i}=0.5 \cdot \pi \cdot D_{i} \cdot c_{f} \cdot \rho_{i} \cdot V_{i}^{2} \cdot d x_{i}
$$


Using the above dependencies, the distribution of the average parameters of the gas flow from the jet engine inside the tubular guide, the friction force on the inner surface of the tubular guide, and the temperature of the wall of the tubular guide from the action of a hightemperature gas jet were calculated for the following parameters: the inner diameter of the guide $D=0.122 \mathrm{~m}$, the length of the guide $L=3.0$ $\mathrm{m}$, the estimated time of the projectile in the guide $\tau=0.131 \mathrm{~s}$, , the critical sectional area of the nozzle of the solid propellant motor $S_{k r}=19.6 \cdot 10^{-4}$ $\mathrm{m}^{2}$, and the cut-off area of the nozzle of the solid propellant motor $S_{a}=75.2 \cdot 10^{-4} \mathrm{~m}^{2}$. The pressure in the chamber of the rocket engine $\mathrm{p}_{\mathrm{c}}=13 \mathrm{mPa}$, the temperature in the chamber of the rocket engine $\mathrm{T}_{\mathrm{K}}=2200 \mathrm{~K}$, the density of the products of combustion of rocket powder in the combustion chamber of the engine $\rho_{c}=17.06 \mathrm{~kg} / \mathrm{m}^{3}$, the specific gas constant for the products of combustion of rocket powder $R_{\mu}=346.42 \mathrm{~J} /(\mathrm{kg} \cdot \mathrm{K})$, the adiabatic index for the products of combustion of rocket powder $k=1,25$, the Prandtl number $\operatorname{Pr}=0.75$, and the Reynolds number at the beginning of the transition zone $\operatorname{Re}_{\mathrm{tr}}=5 \cdot 10^{6}$.

The relative velocity at the nozzle exit of the engine is found from equation (3) by the method of successive approximations. The average flow parameters over the pipe cross section are found according to the theory of supersonic one-dimensional adiabatic gas flows in cylindrical channels of constant cross section, taking into account viscous friction losses in accordance with the Darcy-Weisbach formula and the friction coefficient calculated by the Nikuradze formula (5). The relative velocity at each elementary section of the tubular guide is found from equation (4) by the method of successive approximations. The friction force is calculated on the basis of the theory of a compressible boundary layer taking into account the non-isothermal flow around the inner surface of the tubular guide, the use of relations for friction and heat transfer of the laminar boundary layer, the asymptotic theory for the turbulent boundary layer S. S. Kutateladze and A. I. Leontyev, the theory of turbulent spots of Emmons of the transition boundary layer, and the data on the Reynolds numbers of the beginning of the laminar-turbulent transition obtained in wind tunnels.

Fig. 3 shows the results of the calculations of the friction force of a gas jet on the inner surface of a tubular guide. 


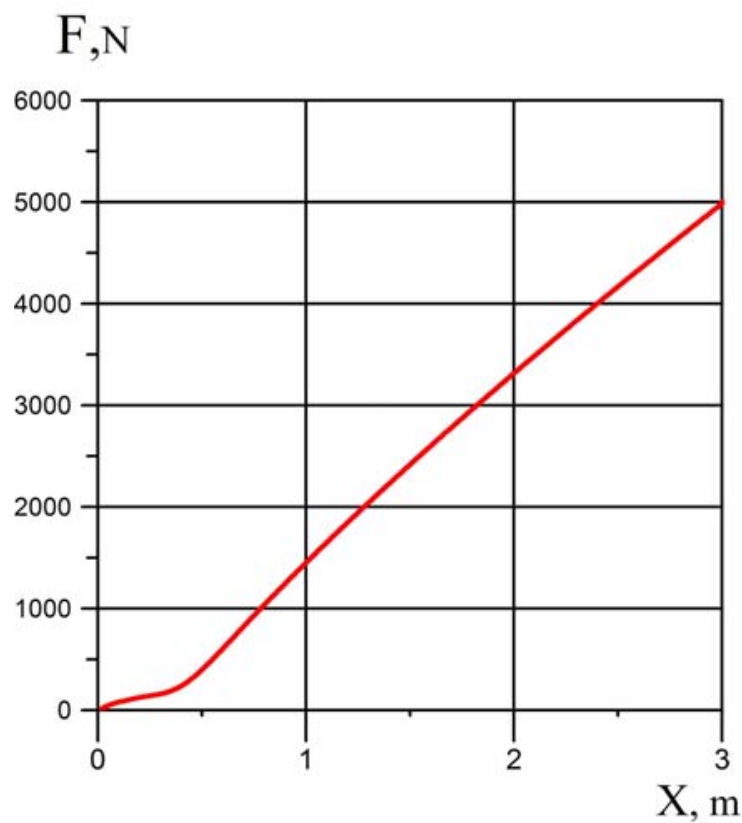

Figure 3 - Calculated dependences of the friction force $F$ of the gas jet on the inner surface of the tubular guide on the displacement $X$ of the nozzle of the projectile's engine inside the guide (the projectile moves from left to right)

Puc. - 3 Расчетная зависимость силы трения $F$ газовой струи на внутренней поверхности трубчатой направляющей от перемещения $X$ среза сопла двигателя снаряда внутри направляющей (снаряд движется слева направо)

Слика - 3 Израчуната зависност силе трења $F$ млаза гаса на унутрашњој површини лансирне цеви од кретања X пресека млазнице мотора пројектила унутар водилице (пројектил се помера са леве на десну страну)

In Fig. 4, the calculated dependence of the Mach number and the relative flow velocity $\lambda$ along the length of the tubular guide at the moment the projectile leaves the guide is shown. The dependences for the velocity and density of the gas flow along the length of the pipe are shown in Fig. 5. Fig. 6 shows the calculated distribution of the dependence of the intermittency coefficient $y$ along the tubular guide length. Fig. 7 presents the calculated dependence of the tubular guide length on its wall temperature calculated using the differential equation for a thin wall, taking into account fluid compressibility and nonisothermality in the boundary layer. The temperature distribution corresponds to the moment the projectile leaves the guide. 
$\operatorname{MAX}, \lambda$

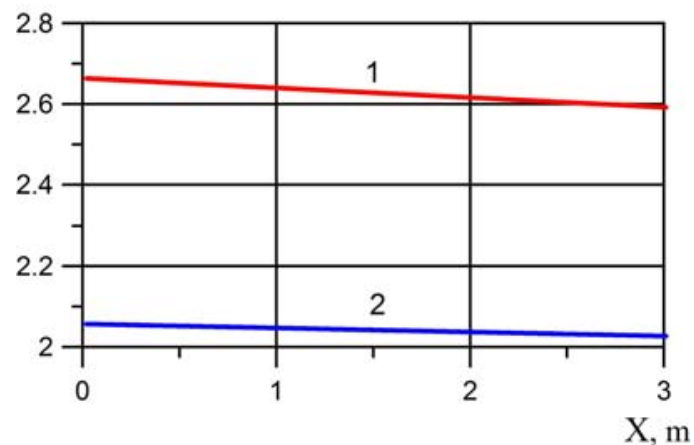

Figure 4-Calculated dependence of the Mach number M (1) and the relative velocity of the gas stream $\lambda$ (2) along the length of the tubular guide at the moment the projectile leaves the guide (the flow moves from right to left)

Puc. 4 - Расчетная зависимость числа Маха M (1) и относительной скорости газового потока $\lambda$ (2) по длине трубчатой направляющей в момент выхода снаряда из направляющей (поток движется справа налево)

Слика 4 - Израчуната зависност маховог броја M (1) и релативне брзине протока гаса $\lambda$ (2) дуж лансирне цеви у тренутку избацивања пројектила из цеви (проток се креће са десне на леву страну)

$\rho, \mathrm{kg} / \mathrm{m}^{3} \mathrm{~V}, \mathrm{~m} / \mathrm{s}$

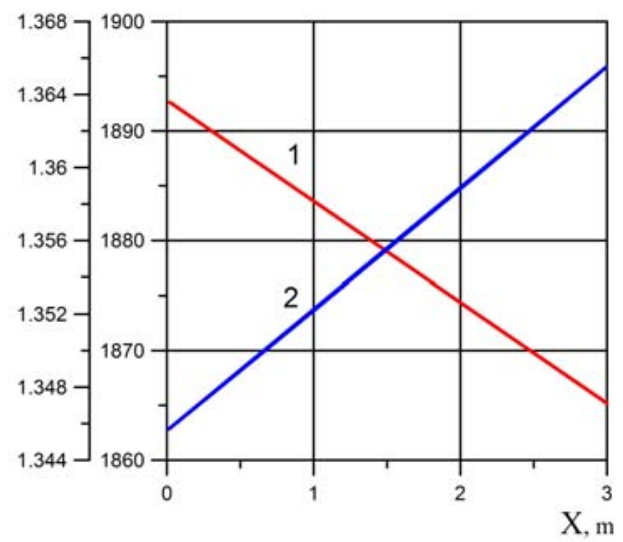

Figure 5 - Calculated dependence of the velocity $V(1)$ and density $\rho(2)$ along the length of the tubular guide at the moment the projectile leaves the guide (the flow moves from left to right)

Puc. 5 - Расчетная зависимость скорости V (1) и плотности $\rho$ (2) по длине трубчатой направляющей в момент выхода снаряда из направляющей (поток движется слева направо)

Слика 5 - Процењена зависност брзине V (1) и густине $\rho$ (2) дуж лансирне цеви у тренутку избацивања пројектила из цеви (проток се помера са леве на десну страну)

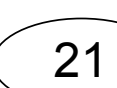




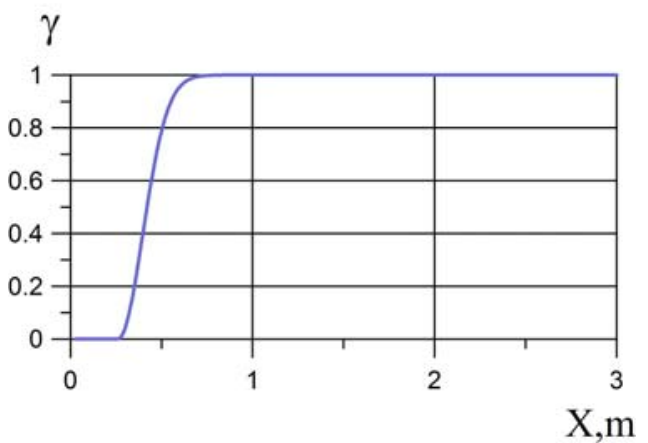

Figure 6 - Calculated dependence of the intermittency coefficient $y$ along the length of the tubular guide at the moment the projectile leaves the guide (the flow moves from left to right)

Puc. 6 - Расчетная зависимость коэффрициента перемежаемости у по длине трубчатой направляющей в момент выхода снаряда из направляющей (поток движется слева направо)

Слика 6 - Процењена зависност коефицијента испрекиданости дуж лансирне цеви у тренутку избацивања пројектила из цеви (проток се помера са леве на десну страну )

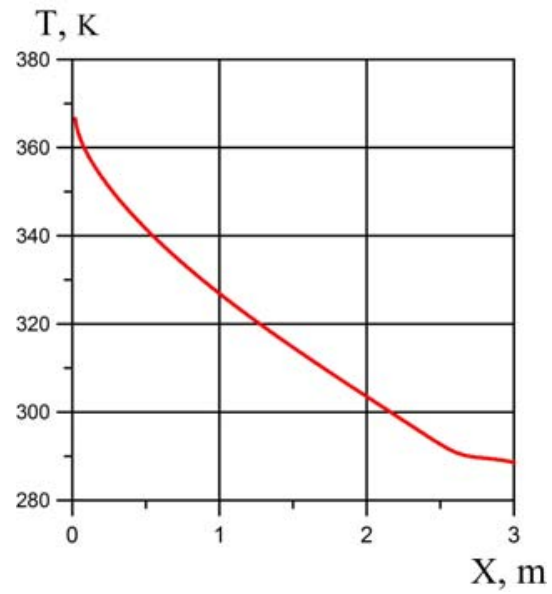

Figure 7 - Calculated dependence for the temperature of the wall $T_{w}$ of the tubular guide along its length at the moment the projectile leaves the guide (the flow moves from right to left)

Puc. 7 - Расчетные значения температуры стенки трубчатой направляющей $T_{\text {w }}$ по ее длине в момент выхода снаряда из направляющей (поток движется справа налево)

Слика 7 - Прорачунате вредности температуре зида лансирне цеви $T_{w}$ дуж цеви у тренутку избацивања пројектила из цеви (проток се креће са десне на леву страну) 


\section{Conclusions}

1. A complex method has been developed for calculating aerodynamic friction and heating on the inner surface of a rocket-guiding tube due to the action of a high temperature supersonic gas jet, taking into account the effects of non-isothermality, compressibility and laminarturbulent transition in the boundary layer on the streamlined inner surface of the tubular guide.

2. The developed method is based on the use of relations for the laminar boundary layer, the asymptotic theory for the turbulent boundary layer of S.S. Kutateladze and A.I. Leontyev, the theory of turbulent spots of Emmons of the transition boundary layer and the data from the Reynolds numbers of the beginning of the laminar-turbulent transition obtained in wind tunnels.

3. The obtained numerical results show calculating the friction force of a high-temperature gas jet on the inner surface of the tubular guide and the temperature of the thin-walled tubular guide when moving inside the guide of a missile with a working engine in real time.

4. The results of the calculations of the gas jet friction force, obtained on the basis of the developed method, can be used to study the dynamics of the launch of rockets from launchers equipped with tubular guides.

\section{References}

Abramovich, G.N. 1991. Prikladnaja gazovaja dinamika. Moscow: Nauka, Glavnaja redakcija fiziko-matematicheskoj literatury (in Russian). (In the original: Абрамович, Г.Н. 1991. Прикладная газовая динамика. Москва: Наука, Главная редакция физико-математической литературы).

Antunevich, A.L., Il'jov, I.G., Goncharenko, V.P.\& Mironov, D.N. 2017. Application of mathematical models for the analysis of complex mechanical system undergoing heterogeneous variable actions. Repository of Belarusian National Technical University, pp.207-213 (in Russian). (In the original: Антуневич, А.Л., Ильёв, И.Г., Гончаренко, В.П., Миронов, Д.Н. 2017. Применение математической модели для анализа сложной механической системы, подверженной неоднородным переменным воздействиям. Репозиторий БНТУ, с.207-213). [online]. Available at: http://rep.bntu.by/handle/data/28261. [Accessed: 21 December 2019].

Bogomolov, A. I. 2003. Osnovanija ustrojstva i raschet reaktivnyh system. Penza: Penza Artillery Engineering Institute (in Russian). (In the original: Богомолов, А.И. 2003. Основания устройства и расчет реактивных систем. Пенза: Пензенский артиллерийский инженерный институт). 


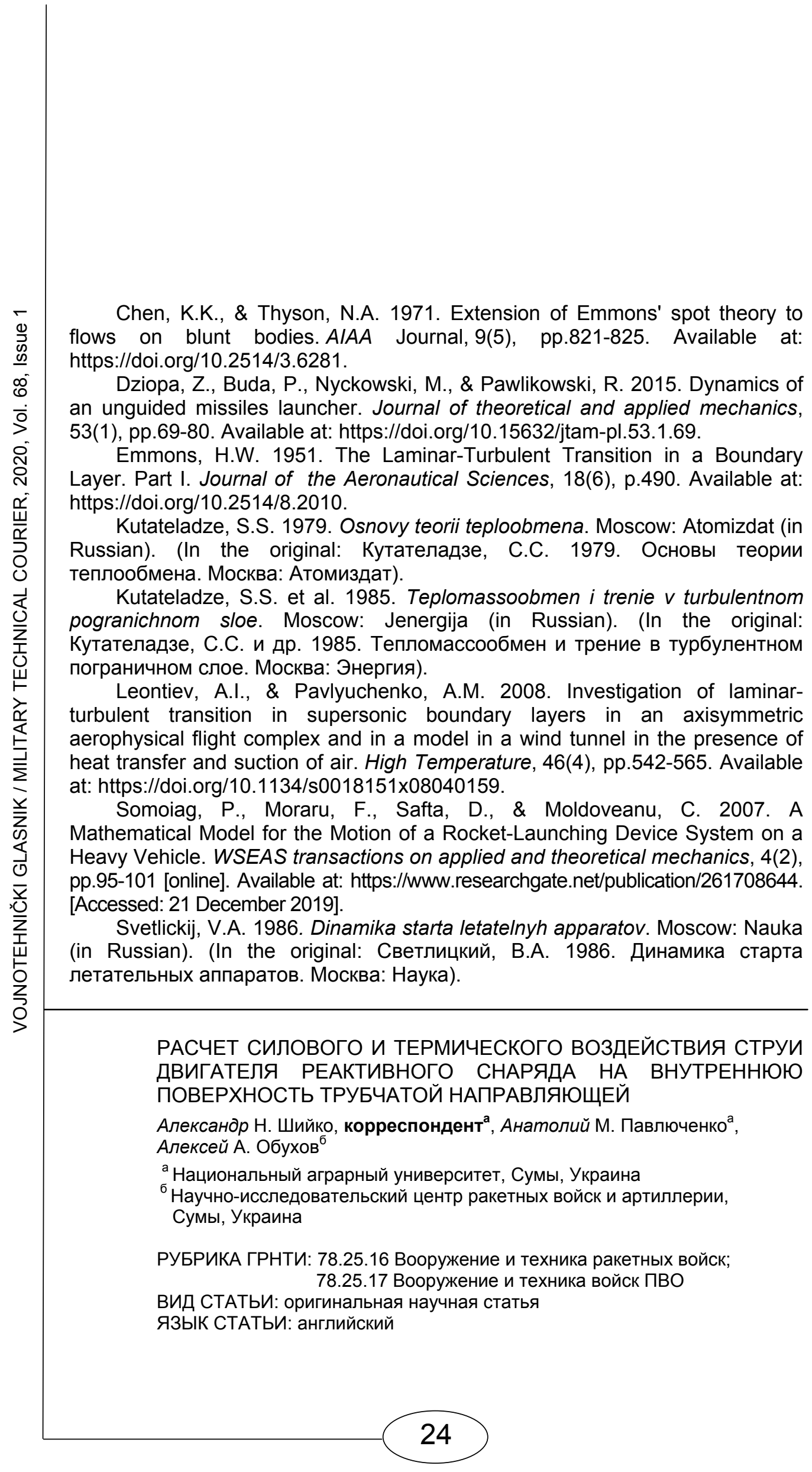


Резюме:

Введение/цель: Для исследования динамики пусковых установок с источниками высокоэнергетических газовых струй актуальным является расчет касательных усилий от действия высокотемпературной сверхзвуковой струи на внутреннюю поверхность цилиндрического канала и температуры стенок канала. Целью данной работы является разработака комплексного метода расчета аэродинамического трения и нагрева на внутренней поверхности трубчатой направляющей реактивного снаряда.

Методы/результаты: Метод исследования основывается на теории сверхзвуковых газовых течений в цилиндрических каналах u теории пограничного слоя. Газовая струя считается непрерывной, стационарной и осесимметричной. Система диффреренциальных уравнений движения снаряда в направляющей интегрируется численно по времени. Параметры потока в сечениях трубы расположены по зависимостям теории сверхзвуковых газовых течений с учетом потерь на трение. Для расчета касательного напряжения на стенке направляющей используются соотношения асимптотической теории турбулентного пограничного слоя, теория турбулентных пятен Эммонса переходного пограничного слоя и данные о числах Рейнольдса начала ламинарно-турбулентного перехода в аэродинамических трубах. В то же время численно интегрируется дифрференциальное уравнение нагрева тонкой стенки направляющей в интервале контакта поверхности направляющей со струей. Выполнены и графически представлены расчеты распределения параметров потока, силы трения и температуры стенки трубчатой направляющей при движении снаряда внутри напавляющей с момента запуска двигателя и до момента полного выхода снаряда из направляющей.

Выводы: Данный метод расчета аэродинамического трения и нагрева на внутренней поверхности трубчатой направляющей реактивного снаряда от высокотемпературной сверхзвуковой газовой струи с учетом эффректов неизотермичности, сжимаемости, ламинарно-турбулентного перехода в пограничном слое, может быть использован при исследовании динамики старта реактивних снарядов из пусковых установок, оборудованных трубчатыми направляющими.

Ключевые слова: пусковая установка, трубчатая направляющая, ракета, реактивный двигатель, пограничный слой, сила трения струи, нагрев трубчатой направляющей. 


\title{
ПРОРАЧУН СИЛЕ ТРЕЊА И ТОПЛОТНОГ УТИЦАЈА МЛАЗА МЛАЗНОГ МОТОРА НА УНУТРАШЬУ ПОВРШИНУ ЛАНСИРНЕ ЦЕВИ
}

\author{
Александар Н. Шијко, аутор за преписку ${ }^{a}$, Анатолиј М. Пављученко ${ }^{\mathrm{a}}$, \\ Алексеј А. Обухов

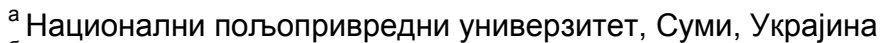 \\ ${ }^{б}$ Научно-истраживачки центар артиљеријско-ракетних јединица, \\ Суми, Украјина
}

ОБЛАСТ: механика, артиљеријско-ракетно наоружање ВРСТА ЧЛАНКА: оригинални научни рад ЈЕЗИК ЧЛАНКА: енглески

\section{Сажетак:}

Увод/циљ: За проучавање динамике лансера са изворима млазева гаса велике енергије важно је израчунати силе смицања услед дејства суперсоничног млаза високе температуре на унутрашњу површину иилиндричног канала и температуру зидова канала. Циљ овог рада јесте развијање свеобухватне методе израчунавања аеродинамичког трења и загревања на унутрашњој површини вишецевног ракетног лансера.

Методе/резултати: Метода истраживања заснована је на теорији струјања гаса при суперсоничним брзинама у цилиндричним каналима и на теорији граничног слоја. Полази се од претпоставке да је млаз гаса непрекидан, стационаран и осносиметричан. Систем диференцијалних једначина кретања пројектила у лансеру нумерички се интегрише с временом. Параметри струјања у деловима цеви утврђују се у зависности од теорије струјања гаса при суперсоничним брзинама, узимајући у обзир губитке због трења. Да би се израчунао напон смицања на зиду лансера, користили су се: однос асимптотске теорије турбулентног граничног слоја, Емонсова теорија турбулентних тачака прелазног граничног слоја, као и подаци о Рејнолдсовим бројевима почетка ламинарно-турбулентне транзиције у аеро-тунелима. Истовремено се интегрише дифреренцијална једначина загревања танког зида лансирне цеви у распону контаката између површине лансера и млаза. Израчуната је расподела параметара струјања, сила трења и температура зида лансирне цеви током кретања пројектила од тренутка покретања мотора до тренутка када пројектил потпуно излази из лансера, ито је и графички представљено.

Закључци: Узимајући у обзир ефректе неизотермичности и стишљивости при прелазу из ламинарног у турбулентни гранични слој, ова метода прорачуна аеродинамичког трења и загревања на унутрашњој површини ракетног лансера, услед 
дејства суперсоничног млаза гаса велике енергије, може да се користи за проучавање динамике лансирања ракета из ракетних лансера који су опремљени лансирним цевима.

Кључне речи: лансер, лансирна цев, ракета, млазни мотор, гранични слој, сила трења млаза, загревање лансирне цеви.

Дата получения статьи / Paper received on / Датум пријема чланка: 30.12.2019. Дата получения откорректированной версии статьи / Manuscript corrections submitted on / Датум достављања исправки рукописа: 14.01.2020.

Дата окончательного согласования статьи / Paper accepted for publishing on / Датум коначног прихватања чланка за објављивање: 16.01.2020.

() 2020 Авторы. Опубликовано в журнале "Военно-технический вестник / Vojnotehnički glasnik / Military Technical Courier" (www.vtg.mod.gov.rs, втг.мо.упр.срб). Данная статья в открытом доступе и распространяется в соответствии с лицензией "Creative Commons" (http://creativecommons.org/licenses/by/3.0/rs/).

(c) 2020 The Authors. Published by Vojnotehnički glasnik / Military Technical Courier (www.vtg.mod.gov.rs, втг.мо.упр.срб). This article is an open access article distributed under the terms and conditions of the Creative Commons Attribution license (http://creativecommons.org/licenses/by/3.0/rs/).

(c) 2020 Аутори. Објавио Војнотехнички гласник / Vojnotehnički glasnik / Military Technical Courier (www.vtg.mod.gov.rs, втг.мо.упр.срб). Ово је чланак отвореног приступа и дистрибуира се у складу са Creative Commons лиценцом (http://creativecommons.org/licenses/by/3.0/rs/). 